\title{
PAUL, THE MAN OF THREE WORLDS: STILL INSPIRING THE CHURCH ACROSS FRONTIERS
}

JM Wessels \& Fika J van Rensburg

New Testament

North-West University

\begin{abstract}
Paul's cultural heritage is often reduced to his Pharisaic background as a Jew. This article not only looks into Paul's broader Graeco-Roman background, but also at the way in which his conversion and subsequent life as a follower of Jesus Christ influenced the way he looked upon his cultural background. This paper also questions the lack of interest from African scholars in Paul's rich cultural background and the way that he utilised it in his ministry. The article concludes with exploratory suggestions for the interpretation of the cross-cultural Paul for the present-day multi-cultural context in Southern Africa.
\end{abstract}

Key Words: Paul, Cultural Diversity, Jewish Heritage, Graeco-Roman Background

\section{Introduction}

In one of the recent commentaries to the book of Romans, Jewett (2007:xv) argues that the motivation for Paul's letter to the Romans was to raise support for his mission to Spain. Moreover, Jewett (2007:xv) acknowledges Bishop Colenso, an earlier missionary to South Africa, as the initiator of his theory. The theme of Colenso's commentary was that all human beings stood equal before God 'in Christ their Head' (Colenso 2003:xxiv), and that there was an analogy between the lack of acceptance between the Jews and the Christians, and the English colonialists and the Zulus.

The central theme that Jewett poses for Romans is not only a clear indication of the current focus on Paul's calling to spread the Word of the Lord amongst the Jews and the gentiles, ${ }^{1}$ but especially in gaining the support of the Jews for his missionary activity. Even though Paul's success record in bringing believers from a Jewish and non-Jewish context together is increasingly questioned (Wedderburn 2004:149-150; Eisenbaum 2000:506-524), Paul's engagement with the Jews and his effort to foster unity in the church is in our view evident in his letters (Wessels 2006:111).

This constant effort of Paul is not only researched by exponents of the 'New Perspective on Paul' (Dunn 2008), but is also relevant for the ongoing process of dialogue between denominations in South Africa and their respective congregations. ${ }^{2}$ Recently Wessels (2007:1) referred to the reason for the lack of engagement with the New Perspective as the scholars being "white, middle class, privileged, and therefore not particularly interested in what the New Testament had to say regarding how contemporary society should be

\footnotetext{
Although it has become customary in scholarly circles to refer to non-Jews rather than Gentiles, the NIV rendering in Romans 15:23 is preferred in the context of this argument.

2 Unity is currently a burning issue in the families of the Nederduits Gereformeerde Kerk, die Gereformeerde Kerke in Suid Afrika, as well as the Nederduitsch Hervormde Kerk.
} 
structured.” It is therefore true that, as amongst the Diaspora Jews in the First Century Mediterranean World, the law and the interpretation thereof can be used in a wrong way to foster separateness and exclusivity.

Not only scholars from the 'white middle class', but African theologians have also lacked interest in Pauline studies. Until recently the main contributions of African New Testament Scholarship was focused on the gospels (Manus 2003:205). Besides publications such as the doctoral thesis of Banda (2004) on 1 Corinthians, and an article by Dube (2004:37-49), relatively few publications have been published by African scholars on Pauline literature in general.

The aim of this article is therefore to look anew at Paul as a product of several cultures, and the way that he was equipped to face multiple challenges in the initial expansion of the church amongst people of different cultures. In conclusion, it is suggested that the new focus upon the cross-cultural reading of Paul can find suitable applications in the current Southern-African context.

\section{The Historical Paul under Scrutiny}

Paul's preparation for his role as mediator in the conflicts that arose when the gospel crossed cultural boundaries, is clearly evident from his background. It is indeed necessary to have a new look into the cross-cultural Paul's person and background from a sociohistorical perspective. The way that personalities were viewed by First Century generations has to be taken into account. It is necessary to be constantly reminded that “...we find nothing in antiquity like the modern notion of culture as a social construction and integrated system of beliefs and practices” (Cosgrove et al 2005:2).

To understand people in the first century, they must be assessed in terms of 'dyadic' personality. The term 'dyadic' is used to indicate that the focus is not primarily upon who a person is, but where he comes from, and where he belongs (Witherington 1998:31). The outward appearance of a person was also very important in the first century AD (Witherington 1998:40). This would mean that a First Century person was mainly measured according to descent, gender and geography (Malina \& Neyrey 1996:153-174).

In discussing the cultural background of Paul, special focus is given to his descent and his geographical background. Biblical passages are established and discussed for their relevance to Paul's background; references to Paul in the Acts of Paul ${ }^{3}$ are also taken into consideration. Previous studies done on the background of Paul is not covered in a separate section, but insights from these studies are utilized in the discussion of Biblical information.

\section{- Paul as a Jew}

Paul identifies himself as a Jew in Philippians 3:4b-5, and the narrative in Acts 21:29 points in the same direction. Paul's reference to his Jewish background in Philippians 3 is indeed laden with status. He was circumcised on the eight day according to Jewish convention, and therefore complied with one of the most important religious symbols of the Jews. He was

The Apocryphal writing, Acts of the Apostle Paul written circa 185-195 AC by a presbyter in Asia Minor (Schneemelcher 1992:351), was disapproved of by Tertullian, whilst Hypollytus of Rome seemed to accept the work as a genuine record of events (Bruce 1977:468). 
also part of God's separate nation, Israel. Paul's focus on his genealogy, as being born from the tribe of Benjamin, should not be underestimated. Paul was not only from the seed of the first king of Israel, but bore his Hebrew name, i.e. Saul. The last reference in this verse, i.e. to Paul as a strict observer of the Law, a Pharisee, would also recall a significant Jewish virtue, namely the observance of the Torah as God's code of conduct for his children.

Considering the above, it is understandable that Paul's Jewish background was never disputed by New Testament scholars. However, the kind of Jew that Paul was is still under contention. This burning issue in New Testament circles is even contested up to the point where the "search for the historical Paul" (in analogy with the search for the historical Jesus) is postulated as a field of research. ${ }^{4}$ One of the main differences in this field of study is the extent of Paul's involvement with the Pharisees. Scholars such as Murphy O`Connor (1996:52-62) and Sanders (1990:8-9) doubt the historicity of Acts 22:3 (placing Paul's education in Jerusalem under Gamaliel), but a growing current consensus is that this information is historically sound (Haacker 2003:21-22; Horrel 2000:25; Witherington 1998:59).

Paul did have close ties with Jerusalem. He tells the Jews in Jerusalem that he was brought up there (Ac 22:3). The word that he uses in this context, $\alpha^{\prime} \nu \alpha \tau \in \theta \rho \alpha \mu \mu \epsilon \in \hat{O}$, refers not only to growing up in his later years in Jerusalem, but also to his early childhood (Haacker 2003:21). Paul also had family there. When there was a plot against him, a son of his sister, who lived in Jerusalem, helped to rescue Paul from the plot against his life (Ac 23:16). According to Acts 21:40-22:2, Paul was also fluent in Aramaic, which increases the probability of an education in Jerusalem.

Paul's reference to being a zealous Pharisee not only in his faultless observance of the Law, but also in persecuting the church, is probably an indication that Paul was not only an ordinary Pharisee, but that he was an 'extremist Pharisee', intent on 'stamping out' those who disagreed with him (Segal 2003:170). Many scholars find Paul’s previous behaviour as an extremist Pharisee incompatible with the moderate behaviour of Gamaliel in treating the Christian apostles in Acts 5:38-39. The education Paul had under Gamaliel, was not necessarily by Gamaliel in person, and not with a specialised future as teacher of the law in mind (Haacker 2003:21-22).

The theory that Haacker relates is not really compatible with the reference to Paul's

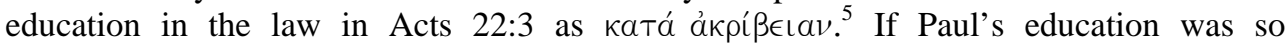
'thorough', and if he refers to himself in Galatians 1:13-14 as "advancing in Judaism beyond many Jews of my age" and "being extremely zealous for the traditions of my forefathers", it does not make sense that he had no personal contact with Gamaliel, or that his education there was of a secondary nature. If one just compares the way the Corinthian congregation deviated from Paul's initial teaching, it is quite possible that Paul could have taken a different course than his teacher.

The dyadic personality of Paul becomes visible in Galatians 1:13-14 where he refers to his Jewish heritage. Paul is not necessarily ashamed of his Jewish heritage. He refers to his Jewish fathers, and to himself as a previous Judaiser. But this is precisely where the dyadic personality of Paul is also overturned. Read carefully, this passage clearly refers to Paul's

\footnotetext{
Cf. the title of Witherington's work, The Paul Quest: A renewed search for the Jew of Tarsus, as well as the chapter on the "historical” Paul by Den Heyer (1998:8-22).

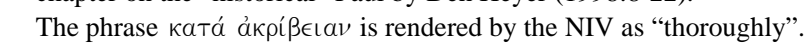


previous life. From a Jewish point of view Paul would have been regarded as an 'apostate' from Judaism. The manner in which Paul argues about the position of Israel in Romans 9:1-11:36 has often been viewed as a positive attitude to Israel, but these three chapters can also be seen as a radical critique of Judaism in the First Century. This passage does contain the hope of salvation for Israel, but actually declares that Israel in its current situation of unbelief is doomed. In recent research Paul's use of the Halakah in especially 1 Corinthians has also drawn attention (Wessels 2005).

Paul's distance from his 'Jewish' heritage is also brought to the surface by his statement in 1 Corinthians 9:20 that he became a 'Jew to the Jews'. It would have been ironic that somebody who is a Jew can become a Jew to the Jews, and this probably refers to 'orthopraxy' rather than 'orthodoxy' (Witherington 1998:64). Despite Paul being circumcised himself, and circumcising Timothy according to Acts 16:3, his view concerning circumcision in Galatians 6:15 reveals his true sentiments. In his conclusion on the Jewish identity of Paul, Witherington (1998:64) evades the dichotomy between Paul being a Diaspora or a Palestine Jew, but describes him as an apocalyptic or messianic Jew. In realizing the identity of Jesus as the true Messiah, Paul now obeyed the new duties of the new creation.

In conclusion, it is clear that whilst Paul was quite comfortable with his Jewish background, he did not focus on his Jewish heritage in dyadic fashion. He only fell back on his Jewish background in polemic situations with Hebrew opponents. This careful referral to his Jewish background would probably explain why the Jews in Acts 21:40 were surprised when they heard Paul speak Aramaic. Paul regretted his persecution of Christians in his previous life as Pharisee, but he was proud of the fact that he did everything with the utmost zeal. Having found the true Messiah, this zeal of Paul was now focused on winning everybody for Christ, and opening their eyes to the identity of the true Messiah.

\section{- Paul as a Citizen of Tarsus and Rome}

There would be very few scholars, if any, who would argue for the primacy of Paul's Hellenistic or Roman background over his Jewish or Hebrew roots, but the Hellenistic and Roman cultures were an undeniable part of Paul's life.

In the work of Den Heyer (1998), Paul: A man of two worlds, the focus is on Paul's Jewish and Greco-Roman origin. In line with this (somewhat artificial) separation between Greek and Roman culture, Wallace \& Williams (1998) divided the Roman and Greek worlds in Paul's life by naming their work The three worlds of Paul of Tarsus. Though a clear-cut distinction between Paul's Greek and Roman background is not followed below, the following seems to substantiate Paul's Greek and Roman heritage.

\section{Born in Tarsus}

The great city of Tarsus, the capital of Cilicia, was probably Paul's (or actually his father's) passport to Roman citizenship. ${ }^{6}$ Paul never mentions in his letters that he was a citizen of

6 After Antiochus Epiphanes IV declared Tarsus a polis in 171 BC, Greek and Jewish colonists were brought in to increase the productivity of the oriental population (Murphy O’Connor 1996:33). In 66 BC it was incorporated into the Roman system by Pompey. Mark Anthony rewarded the city for opposing Cassius, the murderer of Julius Caesar, by giving the city its freedom. This honour was renewed by Caesar Augustus in 
Tarsus or Rome, but it is highly unlikely that the numerous references to Paul's citizenship of Tarsus and of Rome in Acts were merely construed by Luke. In cases where the historicity of Acts is doubted, it is mostly ascribed to the tendency to make the text more Jewish, such as Paul's education in Jerusalem and his use of the synagogue as a starting point for the gospel in foreign cities (Sanders 1990:8-9).

Therefore it would not make sense for Luke to add fictional information (such as Paul's citizenship of Tarsus and Rome) in Acts which would actually 'demote' Paul as an authority amongst the Jewish Christians. The tendency to question Paul's education in Jerusalem from a young age did have the advantage that ample research is available on Tarsus, especially from scholars such as Murphy O’Connor (1996:32-51), who argues that Paul received the bulk of his education (if not all of it) in Tarsus of Cilicia.

Whilst it is disputed that Paul's family originated from Tarsus, Wallace \& Williams (1998:180) in turn question Paul's birth in Tarsus and him enjoying his childhood there. According to them Paul need not have been born physically in Tarsus to be regarded as a citizen of Tarsus (or of Rome), and that Paul had 'obvious' connections in Jerusalem ${ }^{7}$ (Wallace \& Williams 1998:180). Their thesis, however, lacks an explanation for such an addition by Luke.

In view of the lack of additional extra-Biblical evidence, as well as substantial evidence for the opposite, the information rendered to us in the gospel of Luke concerning Paul's citizenship of Tarsus and Rome is accepted for the purpose of this study. The author of Acts not only refers to Paul as coming from Tarsus (Ac 9:11), but he also relates Paul himself declaring in Acts 21:39 that he hails from Tarsus. According to Acts 22:3, where Paul defends himself before the Jews in Jerusalem, he refers to himself as being born in Tarsus of Cilicia, but brought up in Jerusalem.

Accepting Acts' account of Paul's early years as historically correct, i.e. that Paul must have spent most of his education as a child and as a young man in Jerusalem, Paul's eloquence in Koine Greek, as well as his rhetorical capabilities still need explanation. This component of Paul's background is easily answered by the advocates that contend that Paul's childhood education was in Tarsus. Tarsus was not alone a well known trade centre, but also a city known for its education, and instruction in rhetoric (Murphy O’Connor 1996:49). If the theory for the bulk of Paul's education in Jerusalem is upheld, it does not exclude the possible influence of Tarsus on Paul.

Paul's parents probably had Greek as a home language, as was the case with most of the Diaspora Jews. Even in the synagogue the Septuagint was used, and the Jews conducted their business in Greek. Greek was therefore the lingua franca, also for the Jews. The sending of Paul to Jerusalem was probably due his father being a Pharisee (Ac 23:6). For his father it must have been important that Paul was educated in the Jewish law. The existence of a gymnasium in Jerusalem, as well as the presence of a group of Greek Jews (Ac 6:1, 9:29) provides enough reason to believe that Greek was not only spoken in Jerusalem, but that there were ample opportunities to be schooled in rhetoric.

Paul's contact with Tarsus did not end after his childhood years. Although clashing with the information in Paul's letters, the author of Acts relates Paul being sent to Tarsus for his

31 BC, and probably paved the way for a group of citizens to be awarded citizenship of Rome (Murphy O’Connor 1996:33).

7 The connections in Jerusalem refers to possible contacts that Paul built up during his education, as well as his aunt and her son, who lived in Jerusalem (Ac 23:16). 
safety after his conversion (Acts 9:30). Even though this narrative from Luke is not deemed historically sound, it is generally accepted that Paul spent about 11 years (between 35-46 AD) in Cilicia and Syria afterwards (Bruce 1977:275; Witherington 1998:328). It would be highly unlikely that he did not spend some time in his place of birth, and had some kind of contact with rhetoric there. Being outside Jerusalem and Palestine in this time, would also have given Paul (who was evidently highly intelligent), ample time to become fluent in Greek.

\section{Paul as a Citizen of Rome}

Although not uncommon in the Mediterranean world of the first century AD, Paul's dual citizenship of Rome, as well as Tarsus is also doubted by scholars despite clear references to Paul's citizenship as a citizenship by birth in Acts 22:28, and as the numerous references to Paul's citizenship saving him from difficult situations (Ac 22:25; 23:27; 25:11). Despite the fact that Paul had received three beatings (2 Cor 11:25), which was not befitting of a Roman citizen, as well as the difficulties he would have escaping the emperor cult and other religious activities related to the Roman Government, there is relative consensus that Paul was indeed a Roman citizen (Horrel 2000:25).

Paul's citizenship of Rome did not only save him from the chains, or from being beaten by soldiers without a proper hearing. It did also grant him the opportunity to appeal to the Caesar of the day, and therefore it also granted him a passage to Rome, where he really wanted to preach the gospel (Ac 19:21, Rom 1:14-15). His positive interaction with the praetorian guard while under house arrest (see Phil 1) was in part because the guard may not ignore or despise a Roman citizen.

Paul's Roman citizenship also provided him with advantages that would have aided him in his work as a travelling evangelist. Besides having the Roman judicial system at his disposal, he would be allowed entry into any city in the Empire, especially cities of the Roman colonies such as Corinth and Philippi. He would have ready access to Roman roads as well. Paul could also travel with parties other than Roman citizens or even with Roman soldiers on a mission if need be (Witherington 1998:73).

Reference has already been made to Paul's Jewish name, Saul. The common opinion, that Paul's name was changed from Paul to Saul at his conversion, is probably not correct. The most Jews normally had both a Jewish, as well as a Roman name. The name Paulos in

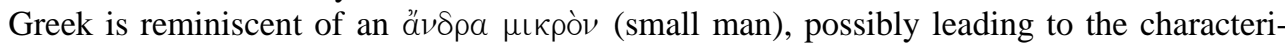
sation of the posture of Paul in the Acts of Paul (1.4). The author of Acts is probably swapping the name Saul with Paul to indicate the transition of his activity to the mission to the Gentiles. The name Saul is, however, also used later in Acts (Ac 22:3-21; 26:9-23), and when Paul's conversion story is retold (Horrel 2000:25).

In conclusion, the question regarding Paul's silence on his citizenship in his letters remains. Paul's silence about his Roman citizenship probably lies on the same level as his scarce references to his Jewish heritage. Paul did in the first place not see his citizenship and his heritage in a dyadic sense. He primarily focused on his citizenship in heaven, and his relationship with Christ, as Philippians 3:20-21 witnesses.

\section{Paul's rhetorical Background}

Even though Paul himself denies the ability to 'speak well' in 2 Corinthians 11:6, this is probably an understatement that must be seen as a rhetorical ploy in itself. It is part of the 
'power through weakness ${ }^{\prime 8}$ approach that Paul follows in 1 and 2 Corinthians. Paul's

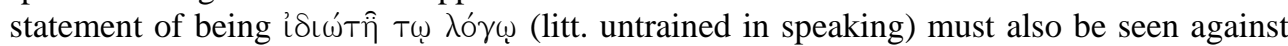
the backdrop of the boasting opponents of Paul in the Corinthian letters. Paul is actually not referring to his own inability to speak, but he is mocking his opponents, as elsewhere in the letter, for reckoning themselves to be rhetorically skilled. ${ }^{9}$ In fact, a study of Paul's letters reveals that he is well skilled in rhetoric (Murphy O’Connor 1996:51).

This analysis of letters from a rhetorical point of view replaced the study of letterwriting in the past few decades (Witherington 2003:263-264). The letter is presently viewed as a "surrogate for oral speech", and a good letter would seek the "best and most persuasive forms of speech possible" (Witherington 1998:119).

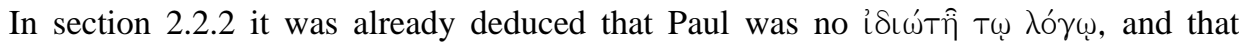
scholars try their best to explain where he received his training as rhetor. Paul did not use 'legalistic aggressivity', as Murphy O’Connor (1996:206) reckons, but he rather preferred to persuade (Witherington 2003:264).

In antiquity rhetoric was basically the art of public speaking, "originally in the public gatherings of the ancient city-states and later especially in trials before magistrates and jury, where both prosecutors and defenders made lengthy speeches intended to persuade the listeners in one way or the other" (Horrel 2000:48).

Paul's rhetorical skill is evident in his letters. In 1 Corinthians 9, for example, the rhetorical topos of the 'enslaved leader' is clear from Paul's approach. The topos of the 'populist leader', striving for power within the patron-client system, is played down against the 'enslaved leader' or demagogue, who becomes a slave for the benefit of his followers (Martin 1990:116). ${ }^{10}$

The use of rhetoric was not just a very productive tool in Paul's time, but is clearly also powerful to explore and analyze Paul's letters today. There are, however, instances where rhetorical analysis may fall short in recognizing the underlying themes in the text (Winter 2003:154), or where a certain text just does not make sense in the light of rhetorical strategies (Tolmie 2004b:487-502). Therefore a holistic way of approaching the text, also accounting for other socio-historical components is vital to understanding the New Testament letters.

\section{- Paul's Christian Background}

The Paul known to us is mainly through his letters after his conversion, and therefore an analysis of Paul's Jewish, Greek and Roman background is not complete without a discussion on Paul as a Christian. Paul's conversion experience on the Damascus road in Acts 9:1-6 is prominent in this regard, and therefore Paul's own reflection on his conversion is used as departure point in this section, with particular reference to Galatians $1: 15-16{ }^{11}$

Cf. the work of Savage (1996) on 2 Corinthians with a similar title.

Cf. 1 Cor 1:17, 2:4; 2:13, 2 Cor 1:12; 10:12, 18

10 The work on Paul as 'Stoic sage' done by Fitzgerald (1978) effectively illustrates Paul's use of the rhetorical conventions of his time.

11 Gal 1:15-17: “" ${ }^{15}$ But when God, who set me apart from birth and called me by his grace, was pleased ${ }^{16}$ to reveal his Son in me so that I might preach him among the Gentiles, I did not consult any man, nor did I go 
Paul structures the account of his conversion with a specific purpose in mind. Describing conversion as a 'sudden change' from his previous life would not be accepted easily within Stoic philosophy (Malina \& Neyrey 1996:39), or in terms of a dyadic personality. He therefore refers to his conversion as being a calling that already originated at his birth. His calling is also connected to the Jewish background. Not only the expression

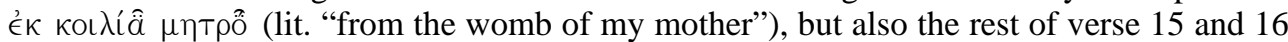
have very strong resemblances to the calling of Isaiah and Jeremiah according to the Septuagint $^{12}$ (Malina \& Neyrey 1996:41, Tolmie 2004a:62-63).

Moreover Paul is referring to the event on the road to Damascus in prophetic terms. The

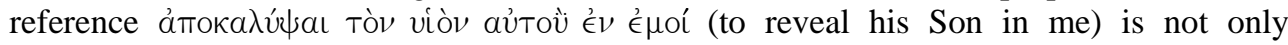
witness to this conversion, but carries the notion that the event of the conversion meant more to Paul that just being a 'turning point' in his life. The linking of the terms in verse 16 referring to a 'revelation' that took place in Paul himself, refers to Paul receiving a divine revelation (Witherington 1998:75).

This theory is supported by Paul's referral in 1 Corinthians 9:1 that he has 'seen' Jesus the Lord, and in Galatians 2:20 that Jesus lives in Him. A further reference to the difference that this vision made in his life, is found in Galatians 4:6, which refers to the 'Spirit of the Son' whom God sent into the hearts of the believers. From the information above it is evident that Paul's Christology is central to his theology. ${ }^{13}$

Paul's baptism after his conversion (Acts 9:18) also contributed to his separation from the Jewish community, and initiation into the Christian community. This contributed to Paul being viewed as a renegade or apostate by the Jews of his time (Witherington 1998:76), and it even resulted in him receiving 'forty lashes minus one' from the Jews (2 Cor 11:23). Even though Paul seems rather indifferent towards baptism in his initial reference to this sacrament in 1 Corinthians 1:7-13, it is evident from 1 Corinthians 12:13 that Paul views baptism as having an important function of bringing people from different cultures together in one new community.

On what Paul did in Arabia, after his conversion on the road to Damascus, there is still difference amongst New Testament Scholars. The growing consensus is that Paul went to Arabia to proclaim the gospel there, being obedient to the command he refers to in Galatians 1:16, i.e. to preach the gospel to the nations (Hengel \& Schwemer 1998: 175-179). On rhetorical grounds there are arguments in favour of the older interpretation, i.e. that Paul went to Arabia to withdraw from human beings or for religious contemplation (Tolmie 2004a:66).

Although decisive evidence in this case is still lacking, it must be noted that Paul proceeded directly from Damascus to Arabia, and came back to Damascus, not visiting Jerusalem for a period of three years (Gal 1:18). Taking into account the 'revelation' he received in Galatians 1:16, and the visions he refers to in 2 Corinthians 12:1, it seems that Paul received the Christian message through revelation. He never refers to any contact with a 'teacher' in the same sense in which he refers to Gamaliel as his Pharisaic teacher in Acts 22:3 (Malina \& Neyrey 1996:41). In summary, the origin of Paul's Christian education can

up to Jerusalem to see those who were apostles before I was, but I went immediately into Arabia and later returned to Damascus."

12 Cf. Isa 49:1, 6 (LXX), Jer 1:5,6 (LXX).

13 The centrality of Christ in Paul's theology is widely accepted (cf. for example Horrel 2000:56; Hurtado 2003:185; Witherington 1998:296). 
be deduced as not originating from human beings, but being a revelation from God (Gal 1:12).

Lastly Paul's spiritual experiences during his early years as a Christian are significant, especially in relation to the Corinthian letters. He did use glossolalia (1 Cor 14:14-15, 18) and also had visions (2 Cor 12:1-6). There are ample references to Paul as a miracle worker, ${ }^{14}$ and Paul also had the gift of prophecy (1 Cor 14:5). All this shows that Paul is not sarcastic when he thanks God for the spiritual gifts of the Corinthians in 1 Corinthians 1:47, but that he "was indeed much more like the Corinthians than many modern commentators like to think" (Witherington 1998:82).

Paul's Christian background cannot be regarded as a 'heritage' as such, but it proved worthwhile to look at Paul's attitude towards his cultural heritage within the framework of Christianity. Being very handy in his knowledge of and approach to the cultures of his day, Paul was able to distance himself from his heritage in order to facilitate the cultural conflicts in the early church.

\section{Conclusion}

In the light of the above the apostle Paul had to grapple with three different cultural worlds in his own background, let alone the cultural worlds of his audiences and readers. The cultural heritage of Paul, being mainly Jewish, his geographical origin, as well as the language and rhetorical trends of the day all played a major role in his life and ministry. Paul retained his zeal after his conversion to Christianity, but his priorities changed dramatically, and he could not be viewed as a true example of a dyadic personality anymore.

In a recent study, Cross-Cultural Paul: Journeys to others, journeys to ourselves (2005), Cosgrove, Weiss and Yeo present a new framework for interpreting Paul in a multicultural society. This challenging study investigates Paul and his message through the lenses of six different cultural groups in modernity.

In conclusion it gives three important hermeneutical departure points in reading Paul, being (1) realizing the cross-cultural gap between us and the historical Paul, (2) distinguishing which things in Paul are 'merely cultural', and (3) taking into account the conflicts between ancient and modern knowledge (Cosgrove et al 2005:272-275). Despite their reservations in interpreting Paul (see also section 2 above), it is important that the authors incite us to look at Paul's techniques in solving cross-cultural conflicts, without necessarily attempting to equate modern-day cultures with Biblical cultures (Cosgrove et al 2005:3).

Reading Paul cross-culturally therefore poses serious challenges to the modern day pastor, especially in the cultural diverse situation of Southern Africa. On the one hand our heritage, education, language, and context compel us to look at Paul for assistance in sensitive cultural issues such as church unity. On the other hand our heritage and background may become 'excessive baggage' and a burden if we are not prepared to forget 'what is behind' and strain towards 'what is ahead' (Php 3:13).

The recent publication of the Africa Bible commentary (Adeyemo 2006) proves that there is a growing interest in Pauline studies and the rest of the New Testament as well. Such an African perspective on Paul and Peter is clear in the comparison that Dube

14 Cf. Ac $13: 1 ; 14: 10 ; 16: 18 ; 19: 11 ; 28: 3-6$. 
(2004:37-49) makes between the apostles' divine experiences and calling. These efforts should be elaborated upon, because there are enough markers that many insights can be drawn from Paul's cross-cultural ministry for our present day context.

At the Victoria Falls in the North of Zimbabwe stands a monument of Sir David Livingstone, with three words on the bottom of his pedestal: 'explorer', 'missionary' and 'liberator'. I believe that there are still frontiers (perhaps now, more than ever) to cross in post-colonisation Africa, albeit of a two-directional and spiritual nature. There are visionary leaders needed to cross these frontiers by becoming slaves in the footsteps of Paul, but ultimately in 'imitatio Christi'. These leaders may even be more controversial than David Livingstone, but (by God's grace alone) the result of their work may be much more fruitful.

\section{BIBLIOGRAPHY}

Acta Pauli et Theclae. Accessed online: http://stephanus.tlg.uci.edu. Date: 23 July 2008.

Adeyemo, T (ed.) 2006. Africa Bible commentary. Grand Rapids. Zondervan.

Banda, DT 2004. New Testament interpretation and African culture: Selections from 1 Corinthians as a test case. Unpublished PhD dissertation at the University of the Free State.

Bible 1989. The Holy Bible. New International Version. Grand Rapids: Zondervan.

Bruce, FF 1977. Paul: Apostle of the free Spirit. Exeter: Paternoster Press.

Colenso, JW 2003. Commentary on Romans. JA Draper, (ed.) Pietermaritzburg: Cluster.

Cosgrove, CH, H Weiss, KK Yeo, (eds.) 2005. Cross-cultural Paul: Journeys to others, Journeys to ourselves. Grand Rapids: Eerdmans.

Den Heyer, CJ 1998. Paul: A man of two worlds. London: SCM Press.

Dube, O 2004. Hold Paul, help Peter: A study in divine activity. Africa Theological Journal 27(1):37-49.

Dunn, JDG 2008. The New Perspective on Paul. Grand Rapids: Eerdmans.

Eisenbaum, P 2000. Is Paul the Father of Misogyny and Antisemitism? Cross Currents 50(4):506-524.

Fitzgerald, JT 1978. Cracks in an earthen vessel: An Examination of the Catalogues of Hardships in the Corinthian Correspondence. Atlanta: Scholar's Press.

Haacker, K 2003. Paul's life. (In JDG. Dunn, (ed.). The Cambridge companion to St. Paul. Cambridge: Cambridge University Press. pp. 19-33).

Hengel, M \& AM Schwemer. 1998. Paulus zwischen Damaskus und Antiochien: Die unbekannten Jahre des Apostels. Tübingen: Mohr Siebeck.

Horrel, DG 2000. An introduction to the study of Paul. London: Continuum.

Hurtado, LW 2003. Paul's Christology. (In The Cambridge companion to St. Paul. Cambridge: Cambridge University Press. pp. 185-198).

Jewett, R 2007. Romans: A commentary. Minneapolis: Fortress Press.

Malina, B \& J Neyrey 1996. Portraits of Paul: An archaeology of ancient personality. Louisville: Westminster John Knox.

Manus, UC 2003. Intercultural hermeneutics in Africa: Methods and approaches. Nairobi: Acton Publishers. 
Martin, DB 1990. Slavery as salvation. New Haven: Inter Varsity Press.

Murphy-O’Connor, J 1996. Paul, a critical life. Oxford: Clarendon Press.

Sanders, EP 1990. Paul. Oxford: Oxford University Press.

Savage, TB 1996. Power through weakness. Paul's understanding of the Christian ministry in 2 Corinthians. Cambridge: University Press.

Schneemelcher, W 1992. New Testament Apocrypha. Vol. 2. Tr. by Wilson, R Louisville: Westminster John Knox.

Segal, AF 2003. Paul's Jewish presuppositions. (In JDG Dunn, (ed.). The Cambridge companion to St. Paul. Cambridge: Cambridge University Press. pp. 159-172).

Tolmie, DF 2004a. A rhetorical analysis of the letter to the Galatians. Unpublished PhD dissertation at the University of the Orange Free State.

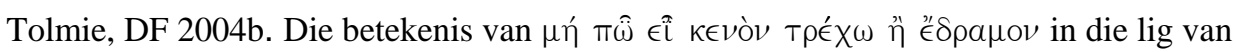
Paulus se retoriese strategie in Gal 1:1-2:10. Hervormde Theologiese Studies 60(1\&2):487-502.

Wallace, R \& W Williams 1998. The three worlds of Paul of Tarsus. London: Routledge.

Wessels, GF 2005. Halakah in the letters of Paul? Unpublished paper delivered at the 2005 NTSSA annual meeting.

Wessels, GF 2007. The new Perspective on Paul - an overview. Unpublished paper delivered at the 2007 meeting of the NTSSA.

Wessels, JM 2006. Paul's approach to the conflict in Corinth: A socio-historic study. Unpublished MTh dissertation at the North-West University, Potchefstroom.

Wedderburn, AJM 2004. A history of the first Christians. T\&T Clark: London.

Winter, BW 2003. The 'Underlays' of conflict and compromise in I Corinthians. (In TJ Burke, JK Elliott, (eds.). Paul and the Corinthians: Studies on a Community in Conflict. Leiden: Brill. pp. 139-155).

Witherington, B 1998. The Paul Quest: Renewed search for the Jew of Tarsus. Downers Grove: InterVarsity Press.

Witherington, B 2003. Contemporary perspectives on Paul. (In Dunn, JDG (ed.). The Cambridge companion to St. Paul. Cambridge: Cambridge University Press. pp. 256-269). 